
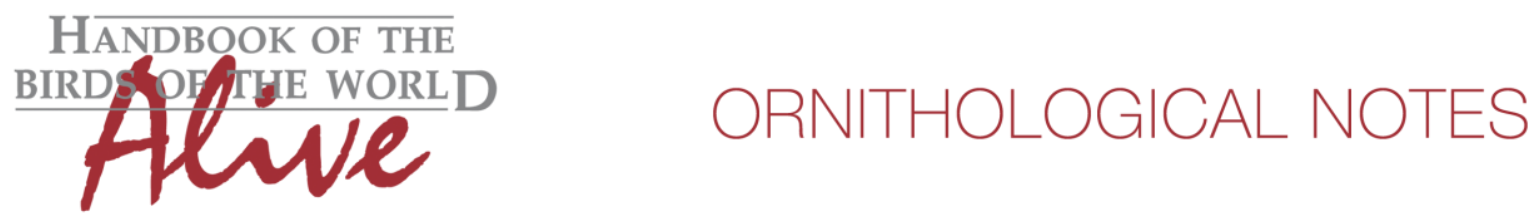

\title{
Notes on the vocalizations of Black-crested Antshrike (Sakesphorus canadensis)
}

\author{
Peter Boesman
}

In the following we briefly analyze and compare voice of the different races of Black-crested Antshrike (Sakesphorus canadensis). We also try to quantify the extent of any vocal differences using the criteria proposed by Tobias et al. (2010), as a support for taxonomic review.

We have made use of sound recordings available on-line from Xeno Canto (XC).

Loudsong of Black-crested Antshrike is a series of notes, which accelerate and rise in pitch towards the end. Song shows little variation among the different races, with the exception of race pulchellus. Unlike other races, song of pulchellus decelerates and drops in pitch towards the end, terminating with some more nasal snarling notes (Fig. 1).

Measurement of some basic parameters of the loudsong:

$$
\text { pulchellus }(n=6)
$$

\# notes

$14-23$

start freq.

end freq.

pace first notes

pace last notes

max. freq.

total length

freq. change last 4 notes

$$
1330-1520 \mathrm{~Hz}
$$

$1015-1580 \mathrm{~Hz}$

$3.5-4.2 \mathrm{n} / \mathrm{s}$

$5.0-6.2 \mathrm{n} / \mathrm{s}$

$1660-1920 \mathrm{~Hz}$

3.20-4.55s

$-330 \mathrm{~Hz}$ to $-800 \mathrm{~Hz}$ other races $(n=8)$

11-19

$1450-1960 \mathrm{~Hz}$

$2150-2810 \mathrm{~Hz}$

$2.5-3.4 \mathrm{n} / \mathrm{s}$

$5.0-7.7 \mathrm{n} / \mathrm{s}$

$2150-2810 \mathrm{~Hz}$

2.77-3.96s

+0 to $+575 \mathrm{~Hz}$

Song of pulchellus differs in its initial faster pace (score 2-3), lower start frequency (score 2), lower max. frequency (score 3), and last notes dropping in pitch (score 3-4) reaching a much lower end frequency (score 3), and with an overall lower acceleration (score 2-3).

Note shapes are also somewhat different, being rather uniform and symmetrical throughout the song phrase in pulchellus, while in other races note shape changes from slightly asymetrical at first to distinctly knife-shaped towards the end.

Above differences result in a total score for vocal difference of 6. 
HANDBOOK OF THE

BIRDS PF, THE WORLD

ORNITHOLOGICAL NOTES

Alive
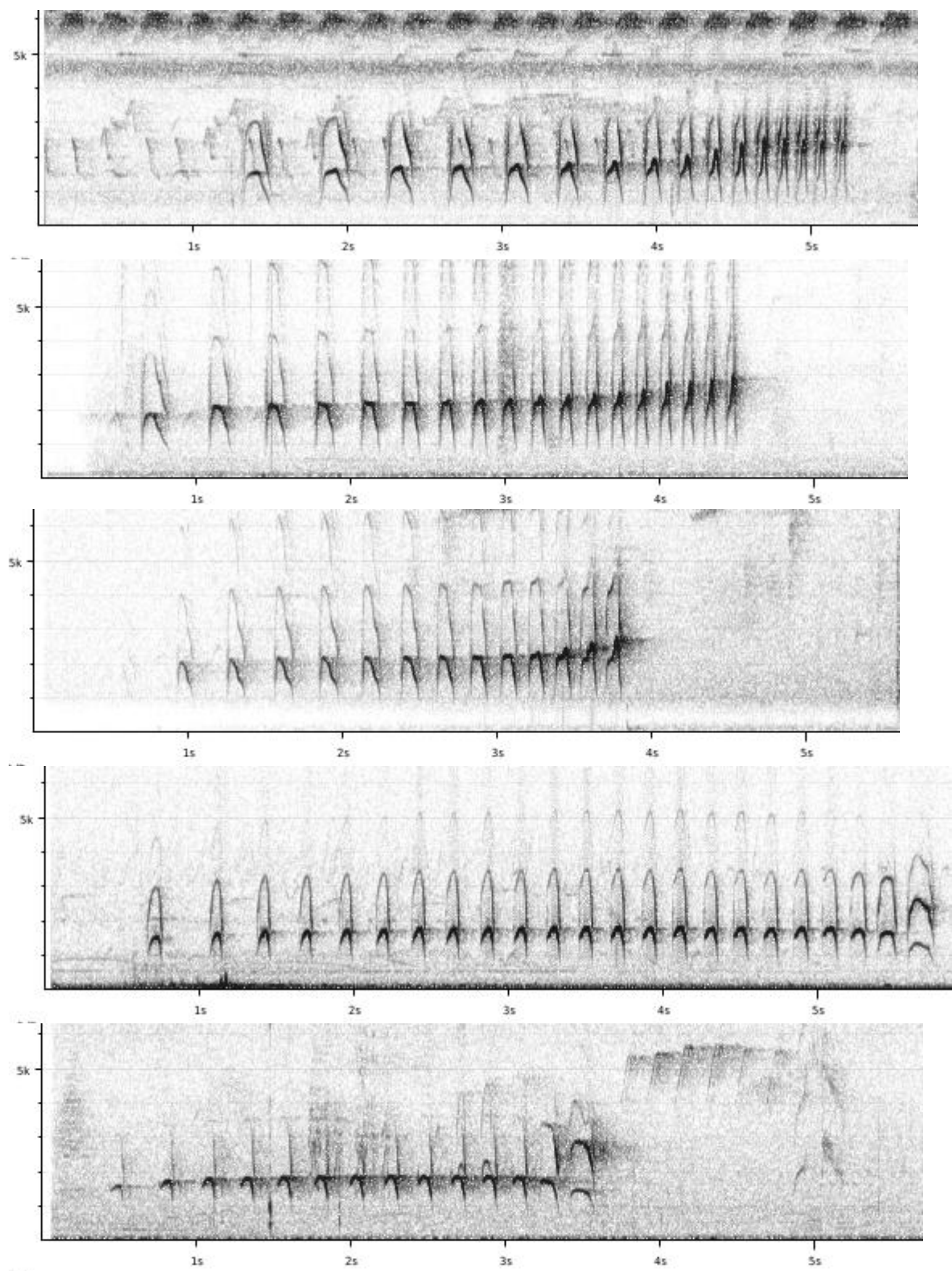

Figure 1: from top to bottom: loudsong of loretoyacuensis, fumosus, intermedius and pulchellus (two examples, resp. Guajira, Colombia and Lara, Venezuela) 
This note was finalized on 18th June 2015 , using sound recordings available on-line at that moment. We would like to thank in particular the many sound recordists who placed their recordings for this species on $\mathrm{XC}$.

\section{References}

Tobias, J.A., Seddon, N., Spottiswoode, C.N., Pilgrim, J.D., Fishpool, L.D.C. \& Collar, N.J. (2010). Quantitative criteria for species delimitation. Ibis 152(4): 724-746.

\section{Recommended citation}

Boesman, P. (2016). Notes on the vocalizations of Black-crested Antshrike (Sakesphorus canadensis). HBW Alive Ornithological Note 52. In: Handbook of the Birds of the World Alive. Lynx Edicions, Barcelona. (retrieved from http://www.hbw.com/node/931931 on 30 April 2016). 